\author{
WIESŁAW BESTRZYŃSKI \\ Uniwersytet im. Adama Mickiewicza \\ w Poznaniu \\ ROBERT SZYMIEC \\ Wyższa Szkoła Języków Obcych \\ w Poznaniu
}

\title{
METODA IMMERSYJNO-MEDIALNA - EDUKACJA ERY SINGULARITY
}

\begin{abstract}
Bestrzyński Wiesław, Szymiec Robert, Metoda immersyjno-medialna - edukacja ery Singularity [The media-immersion method - education for the coming era of Singularity]. „Neodidagmata” 35, Poznań 2013, Adam Mickiewicz University Press, pp. 121-134. ISBN 978-83-232-2685-7. ISSN 0077$653 X$.

The article presents a new teaching method which has been designed for the upcoming Singularity Age. The media-immersion method relies on immersion in the media that is combined with the exploration of the Internet. It also redefines the understanding of learning and competencies in the era of human-computer integration. This method takes advantage of students' already existing motivations and preferences by triggering language acquisition instead of classical learning.

Wiestaw Bestrzyński, Uniwersytet im. Adama Mickiewicza w Poznaniu, Wydział Anglistyki, Al. Niepodlegtości 4, Poznań, Polska - Poland.

Robert Szymiec, Wyższa Szkoła Języków Obcych w Poznaniu, ul. Św. Marcin 59, Poznań, Polska - Poland.
\end{abstract}

\section{ZAŁOŻENIA METODY IMMERSYJNO-MEDIALNEJ}

Prezentujemy opracowaną przez nas autorską metodę nauczania języka angielskiego, opartą na zanurzeniu w mediach i wynikającej stąd akwizycji języka jako zorientowaną przyszłościowo alternatywę dla klasycznego nauczania. Stanowi ona również odpowiedź na cyfrową rewolucję, która zmieniła już świat aktywności, preferencje i percepcję uczniów, a na której w dużej mierze nadal opiera się nasz system edukacji. Poniżej przedstawiamy cechy konstytutywne nowej metody. 
1. Dominującym źródłem zarówno doświadczenia, jak i aktywności językowej staje się cyberprzestrzeń.

2. Wykorzystujemy głównie naturalny proces akwizycji języka, jakościowo inny od nauczania i uczenia się języka.

3. Zmieniamy role nauczyciela i ucznia. Proponujemy wspólną z uczniami eksplorację mediów, w trakcie której stają się oni niezależnymi odkrywcami języka i świata, gdzie nauczyciel staje się przewodnikiem i doradcą kształcącym u nich przez swoją mądrość i dojrzały komentarz kompetencje niezbędne dla niezależnego i krytycznego odbioru nowoczesnych mediów.

4. Rezygnujemy z klasycznego podręcznika, zastępując go selekcją materiałów dostępnych $\mathrm{w}$ Internecie i wybieranych z propozycji przedstawianych przez nauczyciela i uczniów. Aktywności uczniów budujemy na wyrażaniu opinii, dyskusjach i indywidualnych ścieżkach poznawczych zgodnie z semiotyczną perspektywą rozumienia języka jako części procesów poznawania świata i swobodnego wyrażania siebie. Przeciwstawiamy się tu perspektywie odtwórczej i zorientowanemu na testy skrzywieniu doświadczenia językowego dominującego obecnie w szkołach.

5. Klasyczne strategie nauczania stosujemy wyłącznie dla tematów związanych z gramatyką; jak wynika z naszego doświadczenia, to jedyny obszar, w którym instrukcje formalne są przydatne dla uzupełnienia spontanicznej akwizycji języka.

6. Rezygnujemy $\mathrm{z}$ pamięciowego opanowywania kolejnych działów słownictwa i ich testowego sprawdzania na rzecz nowoczesnego, wspieranego komputerowo nauczania opartego, naszym zdaniem, na najbardziej efektywnym systemie Super Memo.

\section{SINGULARITY - EDUKACJI DLA PRZYSZŁOŚCI}

Uważamy, że dzięki powyższym założeniom proponujemy metodę, która wykracza poza granice metodyki nauczania języków obcych. Wpisuje się ona w hasło „Edukacji dla przyszłości”, której wyznacznikiem jest szeroko obecnie dyskutowane zjawisko Singularity, czyli funkcjonalnego zespolenia człowieka z maszyną. Nie chodzi tu oczywiście o zaproponowaną przez Kurzweila perspektywę przeniesienia ludzkiej świadomości do superkomputera (co ma być, według niego, technicznie możliwe najpóźniej do roku 2045), ale o aspekt funkcjonalny takiego zespolenia. Mówimy więc tu o integracji na płaszczyźnie działań intelektualnych w ramach coraz lepiej funkcjonujących interfejsów między człowiekiem i maszyną. Tak rozumiane Singularity jest obecnie pojęciem kluczowym dla uzyskania przyszłościowej perspektywy rozumienia zjawisk kulturowych, relacji społecznych 
oraz wynikających z nich nowych kompetencji merytorycznych wymaganych dla funkcjonowania w świecie Singularity. Uzasadnione zatem wydaje się zupełnie nowe rozumienie efektywnego procesu uczenia się oraz wynikających stąd nowych zadań dla edukacji. Zamiast dotychczasowego modelu pamięciowego gromadzenia wiedzy powinniśmy przejść na model zespolony, w którym funkcję magazynowania informacji przejmuje maszyna, z którą jest nierozerwalnie połączony człowiek przyszłości. W takim rozumieniu duża część zajęć prowadzonych obecnie na wszystkich stopniach edukacji ma bardzo znikomą wartość dla ich odbiorców w przewidywalnej przyszłości. Odtwarzanie pamięciowe wiedzy, nagradzane $w$ tradycyjnych systemach edukacyjnych, jest bowiem $w$ erze cyfrowej anachronizmem. Kluczem do sukcesu natomiast będzie umiejętność korzystania z nowej informacji i przetwarzanie jej w sposób twórczy w ramach ciągle ewoluującej technologii. Kształtowanie takich umiejętności może się okazać jedną z największych wartości edukacji współczesnej, gdyż

Wśród kompetencji charakteryzujących współczesnego wykształconego człowieka funkcjonalna znajomość mediów wybija się na plan pierwszy, pozwoli mu bowiem nie tylko zdobyć najlepsze wykształcenie, ale lepiej funkcjonować na rynku pracy oraz uczestniczyć w życiu społecznym (Skrzydlewski, 2004, s. 41).

To z kolei wymaga przygotowania uczniów do „świadomego, krytycznego i wartościującego odbioru wszelkiego rodzaju komunikatów (przekazów) medialnych" (Strykowski, 2004, s. 38). W takim rozumieniu nasza metoda dotyczy całego obszaru edukacji, gdyż zajęcia na niej oparte mogą stanowić część lekcji z każdego przedmiotu. Ponieważ wynika ona również z ekstrapolacji trendów, które ukształtowały medialną charakterystykę dnia dzisiejszego, jesteśmy ufni, że taka właśnie będzie przyszłość edukacji. Im prędzej zaczniemy w sposób rzeczywisty unowocześniać szkolnictwo, tym lepiej, gdyż samo wyposażenie szkół w komputery i tablice interaktywne (które służą głównie za projektory wyświetlające zawartość tradycyjnych z natury podręczników) nie zmienia jakościowo sedna doświadczenia edukacyjnego. Warto podkreślić, że wiele tradycyjnych podręczników jest obecnie wyposażonych $\mathrm{w}$ dodatki multimedialne, które pozwalają na przeniesienie zawartości książki na tablicę interaktywną. Taka strategia redukuje ogromny interaktywny potencjał nowoczesnych mediów do poziomu staromodnego rzutnika do przeźroczy. Nadszedł więc czas na cyfrową i twórcza rewolucję.

\section{METODA IMMERSYJNO-MEDIALNA NA TLE INNYCH METOD}

Istniejące metody nauczania były zawsze uwarunkowane aktualnie potrzebami, środkami i dostępnymi urządzeniami technicznymi, rozumie- 
niem tego, czym jest język oraz ciągle zmieniającymi się definicjami uczenia się jako procesu, które wyznaczał postęp w psychologii. Suma tych uwarunkowań i wynikających $\mathrm{z}$ nich wyborów (które pojawiały się $\mathrm{w}$ różnych konfiguracjach) określała ich charakter. W glottodydaktyce istnieje podstawowy podział na metody konwencjonalne i niekonwencjonalne nauczania języków obcych.

Metody konwencjonalne zazwyczaj odwzorowywały aktualnie dominujące $\mathrm{w}$ psychologii teorie uczenia się lub koncentrowały się na jednym wybranym aspekcie aktywności językowych, uznając go za najważniejszy dla efektywnego nauczania. Na przykład metoda gramatyczno-łłumaczeniowa została uformowana pod wpływem założenia, że kompetencje językowe mają służyć prawie wyłącznie do tłumaczenia na język ojczysty tekstów pisanych w języku obcym, natomiast aspekt komunikacyjny był pozbawiony praktycznego znaczenia. Kolejną metodą używaną równolegle z metodą gramatyczno-tłumaczeniową była metoda bezpośrednia wynikająca z potrzeby komunikacji werbalnej. Wykorzystywała ona jako nauczyciela native speakera. Typowym dla tej metody nauczycielem była obcojęzyczna guwernantka. Audiolingwalizm był odpowiedzią na sytuację, która powstała w czasie drugiej wojny światowej, kiedy pojawiła się potrzeba szybkiego nauczenia żołnierzy podstawowych kompetencji komunikacyjnych. Nie do końca spełniła swoją rolę, ponieważ nie zawierała elementów kreatywności, a nauczanie polegało na powtarzaniu gotowych zdań, co miało uniemożliwić powstawanie błędów. Metoda kognitywna nawiązywała do zmodyfikowanej metody gramatyczno-tłumaczeniowej.

W metodach niekonwencjonalnych brane są pod uwagę między innymi różnice indywidualne między uczniami lub akcentowane różne aspekty aktywności językowych. Jedną z najbardziej ulubionych przez nauczycieli i uczniów metod niekonwencjonalnych jest TPR (reagowanie całym ciałem). Metoda ta uznawana jest za najodpowiedniejszą dla najmłodszych grup wiekowych uczniów. Zawiera elementy zabawy i unika ewentualnych problemów związanych z czasowymi ograniczeniami skupienia uwagi u dzieci. Inną metodą jest SilentWay, w której uczniowie nie są zmuszani do aktywności językowej i podejmują ją dopiero, gdy są do tego gotowi. Metoda CLL wykorzystywała techniki psychoanalityczne i terapeutyczne. Natural Method starała się odwzorować naturalne środowisko uczenia się języka rodzimego. Suggestopedia opierała się na założeniu, że stan relaksacji powoduje wykorzystanie rezerw ludzkiego mózgu. Task Based Learning akcentuje związek używania języka z realizacją prostych zadań, na przykład kupno biletu na autobus. Przed uczniami stawia się zadania do realizacji, co ma doprowadzić do aktywizacji ich kompetencji językowych. 
Metoda oparta na zanurzeniu w mediach wymyka się tym podziałom. Proponowana przez nas metoda różni się od przedstawionych powyżej tym, że nie stanowi jedynie zaakcentowania pewnych aktywności językowych, ale jest odpowiedzią na rewolucję społeczno-technologiczną wieku cyfrowego. Mówimy tu zatem o dwóch płaszczyznach, które zmieniają jakościowo zarówno ucznia, jak też świat, w którym on funkcjonuje. Zatem nasza metoda nauczania języka angielskiego nie należy właściwie do żadnej z tych kategorii (choć można by z pewnością nazwać ją niekonwencjonalną). Dodatkowo wpisuje się w preferencje pozaszkolne współczesnej młodzieży, która postrzega aktywności związane z mediami cyfrowymi jako zbyt atrakcyjne w porównaniu do pozostałych (Strykowska, 2013).

Mówimy tu o medialności dominującej takie kategorie, jak: jakościowo nowa charakterystyka odbiorcy edukacji ery cyfrowej, trendy i urządzenia techniczne (jako odzwierciedlenie kierunku rozwoju technologii i preferencji odbiorcy tej metody edukacyjnej), rozumienie tego, czym jest język (w ujęciu semiotycznym język przenika każdy akt komunikacji i jest zespolony $\mathrm{z}$ poznawaniem świata) oraz nowe rozumienie procesu uczenia się $\mathrm{w}$ psychologii (mówimy tu o zaakcentowaniu perspektywy konstruktywistycznej $\mathrm{z}$ elementami metakognitywistyki, w połączeniu z dewaluacją wartości wiedzy jako pamięciowo przyswojonego zbioru faktów). Przede wszystkim jednak adaptujemy nasz model edukacyjny do nowej jakościowo charakterystyki odbiorcy edukacji ery cyfrowej, ponieważ to dla niego przede wszystkim projektujemy doświadczenie edukacyjne.

Przyjrzyjmy się teraz bliżej odbiorcy takiej edukacji i samemu procesowi uczenia się.

\section{ODBIORCA EDUKACJI W NADCHODZĄCEJ ERZE SINGULARITY}

Kanadyjskie Centrum Edukacji Medialnej w artykule zatytułowanym Uzasadnienie dla edukacji medialnej w klasie wskazuje, że "media są nie tylko źródłem rozrywki i informacji, ale doświadczeniem które definiuje nasz styl życia" (Andersen, 2009, s. 1). Cechami definiującymi i wyróżniającymi uczniów ery cyfrowej są przede wszystkim: intensywne codzienne zanurzenie $\mathrm{w}$ mediach (połączone $\mathrm{z}$ niechęcią do studiowania długich tekstów pisanych), niezależność $w$ wybieraniu ścieżek i strategii poznawczych (wraz z brakiem akceptacji dla nauczania tradycyjnego), intensywna komunikatywność, dziejąca się głównie w sposób spontaniczny na różnych płaszczyznach elektronicznych, oraz wielozadaniowość. Tradycyjna szkoła walczy z multitaskingiem, na przykład odbierając uczniowi możliwość używania telefonu komórkowego, tabletu i innych urządzeń medialnych 
w imię poprawienia jego skupienia na lekcji, co często skutkuje rozdrażnieniem i permanentnym brakiem skupienia.

$Z$ naszych spostrzeżeń czynionych podczas praktyki edukacyjnej (jak również z rozmów z innymi nauczycielami oraz uczniami z różnych szkół) wynika, że odbiorcy edukacji na wszystkich jej poziomach wydają się coraz bardziej preferować elektroniczne oraz multimedialne źródła wiedzy i umiejętności. Tendencja ta jest tym silniejsza im niżej schodzimy $w$ uczniowskich grupach wiekowych. Potwierdzają te nieformalne spostrzeżenia również źródła naukowe. Jak donosi serwis informacyjny Daily Mail (2012, s. 1): „Najnowsze statystyki pokazują, że dzieci w wieku 12-15 lat spędzają przeciętnie ponad 6 godzin z nosem przyklejonym do ekranu. Szokująco te dane odnoszą się wyłącznie do ekspozycji na media w domu i nie dotyczą użytkowania komputera ani gadżetów takich jak smartfony w czasie wolnym". W związku z tak dużą ekspozycją na nowe media (która wynika z wyborów niewymuszonych na młodzieży, ale z ich własnych preferencji, zainteresowań i charakterystycznych dla nowych mediów sposobów uczenia się) powinniśmy przedefiniować charakterystykę odbiorcy edukacji z uczestnika wykładu, gdzie wiedza przepływa jednokierunkowo od nauczyciela do ucznia, na ucznia, który jest podmiotem interakcji edukacyjnej. Jego preferencje to aktywne poszukiwanie i odkrywanie wiedzy przebiegające $\mathrm{w}$ ramach procesu zanurzenia $\mathrm{w}$ nowoczesnych mediach. Zanurzenie to ma formę interaktywną i jest lepszym terminem dla określenia takich aktywności niż ekspozycja na media. Ekspozycja byłaby właściwym słowem dla odbiorców programów telewizyjnych, którzy właściwie pozostają bierni podczas oglądania.

Uczniowi ery cyfrowej towarzyszy w jego aktywnościach również intensywna komunikacja elektroniczna $\mathrm{z}$ innymi członkami grup rówieśniczych, często istniejącymi wyłącznie na płaszczyźnie internetowej. Jeśli przyjmiemy taką perspektywę na dominujący charakter medialnych aktywności intelektualno-komunikacyjnych jako charakterystyczną dla współczesnego podmiotu edukacji, to powinno to stanowić indykator dla przeorientowania koncepcji edukacji jako takiej, poprzez zastąpienie nauczania tradycyjnego nauczaniem immersyjnym opartym na koncepcjach konstruktywizmu. To umożliwi uczniowi, w ramach przyznanej mu niezależności, konstruowanie wiedzy i umiejętności w sposób aktywny poprzez partycypację w aktach komunikacji oraz eksploracji mediów i zasobów Internetu. Jeśli spojrzeć na ucznia jako integralną część grupy, to dodatkową społeczną korzyścią, którą przyniesie nam przeorientowanie na nowoczesne media, będzie egalitaryzm wynikający $\mathrm{z}$ naszych aktywności w środowisku internetowym, które „jest bardziej równorzędne jeśli chodzi o status rozmówców w porównaniu do komunikacji twarzą w twarz, ponieważ czyn- 
niki takie, jak atrakcyjność osobista, prestiż społeczny i dobra materialne nie odgrywają żadnej roli w dyskusji" (Eggen, Kauchak, 2004, s. 87).

Możemy więc stwierdzić, że korzystne dla odbiorcy edukacji ery cyfrowej będzie odpowiadające jego charakterystyce, nasycone mediami otoczenie umożliwiające jak najbardziej wygodne i spontaniczne dla niego funkcjonowanie, a więc otoczenie i aktywności wykorzystujące multitasking. Takie nabywanie wiedzy lub umiejętności zagwarantuje mu niezależność poprzez stały dostęp do zasobów Internetu, multimedialną zawartość i charakterystykę treści edukacyjnych oraz otwarte schematy zajęć lekcyjnych wymagające i pozwalające na aktywne działania ucznia w ramach konstruktywistycznego pojmowania zjawiska uczenia się. Wartością dodatkową tak prowadzonych zajęć jest przygotowanie do świadomego i krytycznego uczestnictwa w różnych aspektach funkcjonowania mediów współczesnych, ponieważ dla uczniów „bardzo ważne jest zrozumienie, że każdego dnia oddziałują na nas setki wiadomości, które wpływają na nasze postawy, wartości i zachowanie - nie zawsze świadomie" (Dylak, 2004, s. 99). Zadaniem światłego nauczyciela jest zatem współuczestnictwo w świecie medialnym, który jest również światem jego uczniów.

\section{CZYM JEST PROCES UCZENIA SIĘ W ERZE SINGULARITY}

Zapamiętywanie jest mechanizmem adaptacyjnym, które mózg osoby zanurzonej w jakiejś aktywności wykonuje dynamicznie i selektywnie $\mathrm{w}$ zależności od potrzeb. Wymuszanie zapamiętywania jest więc anachronizmem wynikającym z przekonania o wyższości systemu administracyjnego kontrolującego edukację nad kreatywnym i konstruktywistycznym rozumieniem uczenia się. Ulubionym argumentem edukatorów wymuszających pamięciowe opanowywanie dużych porcji materiału jest to, że bez "pewnej podstawowej wiedzy" uczniowie nie będą „kompetentni". Przyjrzyjmy się temu na przykładzie królowej nauk - matematyki. W tradycyjnym rozumowaniu im więcej wzorów i współczynników uczeń pamięta, tym lepiej. Prawda? Niekoniecznie. Uczeń, który wkuł na pamięć całe tablice matematyczne wraz z zamieszczonymi na nich wzorami, nie jest najlepszym matematykiem $w$ szkole i prawdopodobnie nigdy nim nie będzie, ponieważ zmarnował za dużo czasu na przyswajanie niepotrzebnej informacji, zamiast rozwiązywać zadania. Dodatkowo uczeń, który rozwiązuje dużo zadań, korzystając z tych samych tablic, zapamięta selektywnie najczęściej używane wzory i stałe. Oznacza to ekonomizację pracy i pamięci, którą gwarantuje fakt, iż za selekcję zapamiętywania odpowiada jego mózg, a nie biurokrata ustalający program nauczania. 
W dydaktyce przyjmuje się, że uczenie się to nade wszystko systematyzowanie wiedzy, ale szczególnie obecnie, a dokładnie mówiąc w erze wszechobecnej informacji, można pokusić się o rewizję tego stwierdzenia. Uczenie się to chaos, a całość tej pozornej sprzeczności obejmuje teoria chaosu złożoności, czyli wyłaniania się porządku z tak zwanego chaosu, który, jak się okazuje, chaotyczny nie jest. To, co na pierwszy rzut oka odbieramy jako chaos, oznacza jedynie wyższą lub bardziej skomplikowaną formę organizacji, której nie potrafimy jednoznacznie zinterpretować, która nie poddaje się redukcjonistycznemu rozumowaniu, ale prowadzi do wyłaniania się zauważalnego porządku.

Uczenie się jest taką właśnie umiejętnością sieci neuronowych. Nie możemy rozsądnie oczekiwać, że będzie przebiegało w sposób liniowy i na dodatek podobny u różnych uczniów. „Wrażliwość systemów złożonych na warunki początkowe jest śmiercią redukcjonizmu" (Baranger, 2006, s. 7). Założenia tradycyjnej edukacji wynikają z przyjęcia redukcjonizmu do wyjaśniania i ewaluacji procesów uczenia się. Procesy uczenia się nie są jednak oparte na założeniu liniowym i dlatego perspektywa redukcjonistyczna nie jest w stanie ich objąć. Są one wielowymiarowe, dynamiczne chronologicznie i nie dają się nawet we wszystkich aspektach określić ani tym bardziej przewidzieć, podobnie jak stany energetyczne pojedynczego atomu. Dlatego w naszej metodzie jako składniku edukacji przyszłości akwizycja i wyłanianie się wiedzy lub systemu językowego zastępują klasyczne nauczanie. Teoria chaosu - złożoności obrazuje, jak z niewyobrażalnego chaosu połączeń neuronowych wyłania się uporządkowanie i koncepcjonowanie świata. Jeśli zatem chcemy zoptymalizować proces uczenia się i nauczania, to musimy zorganizować go w sposób uwzględniający naturalne pryncypia procesu uczenia się jako procesu twórczego, konstruktywistycznego i z natury rzeczy chaotycznego. Dodatkowo proces ten przebiega niepowtarzalnym tropem dla każdego z uczniów - co jest uzasadnione neurologicznie, społecznie i nawet językowo. Sandra Bloom, psychiatra z USA, uważa, że teoria chaosu - złożoności w odniesieniu do rozumienia człowieka niesie z sobą obietnicę, że „istnieje coś poza fragmentarycznym, redukcjonistycznym i nastawionym na eksploatację modelem natury człowieka - który to model atakuje nas obecnie z każdej strony" (Bloom, 2000, s. 4).

$\mathrm{W}$ takim przypadku organizowanie edukacji w sposób z góry zaplanowany jest działaniem przeciwnym samej naturze uczenia się i sprzecznym z ludzką potrzebą samostanowienia, która w myśl Self-Determination Theory (teoria samookreślenia) jest warunkiem koniecznym akceptacji i internalizacji ludzkich aktywności, a szczególnie uczenia się.

W odniesieniu do procesów uczenia się wykorzystujących zanurzenie w mediach możemy powiedzieć, że 
Jest imperatywem to, aby nauczyciele zrozumieli uczenie się i PROCESY przetwarzania informacji. Nauczyciele zakładali kiedyś, że są jedynym źródłem informacji. Nowe technologie spersonalizowały uczenie się, otwierając drzwi eksploracji, odkryciu i procesom wykonawczym, które personalizują uczenie się, przekształcając je w doświadczenie osobiste, aktywne, a nawet chaotyczne (Scharf, 2002, s. 2).

Czym jest zatem prawdziwe i efektywne uczenie się w erze cyfrowej, jeśli uczenie się pamięciowe ma nikły sens? Wydaje się, że powinniśmy uczyć umiejętności uczenia się bardziej niż treści edukacji samych w sobie. Koncepcją, do której nawiązuje taki punkt widzenia, jest metakognitywizm. „Badania nad metapoznaniem miały historyczną wagę, ponieważ podkreślały aktywny udział ucznia w procesie uczenia się" (Miltiadis, 2008, s. 152)

Omawiając praktyczne implikacje oparcia nauczania języka angielskiego na teorii systemów złożonych Harshbargera, między innymi postuluje się, żeby:

Zamiast narzucać sztywne i standaryzowane jednakowo dla wszystkich metody pedagogiczne i materiały, edukatorzy i programy edukacyjne skupią się na dostarczaniu uczniom bogatego środowiska stymulującego połączonego ze zróżnicowanymi interesującymi i wciągającymi aktywnościami, które promują zindywidualizowane uczenie się, materiały które są personalnie ważne i wynikają z zainteresowań pojedynczych uczniów (Harshbarger, 2005 s. 15).

Właśnie takie otoczenie i wynikające $\mathrm{z}$ niego zindywidualizowane ścieżki uczenia się proponujemy jako podstawę doświadczenia językowego będącego połączeniem zanurzenia w mediach oraz immersji językowej.

\section{IMMERSJA JAKO MECHANIZM NABYWANIA KOMPETENCJI (RÓWNIEŻ) JĘZYKOWYCH}

Chcąc właściwie rozumieć termin „immersji” (lub zanurzenia w języku czy w mediach), proponujemy następującą definicję. Słowo „immersja” oznacza fizyczne zanurzenie przedmiotu $w$ cieczy. W odniesieniu do języka określa ono stan, w którym osoba podświadomie nabywa kompetencji językowych na skutek zanurzenia w rzeczywistości nowego dla niej języka. W nauczaniu języka, immersja oznacza kurs językowy, w którym język obcy jest jednocześnie jedynym językiem używanym w trakcie zajęć. Immersja jest więc, matematycznie rzecz ujmując, wystarczająco dużą totalną sumą procesów informacyjnych (językowych i pozajęzykowych współtworzących akty komunikacyjne i poznawcze), na skutek której w mózgu osoby zanurzonej w takim środowisku językowym uruchamiają się, bez udziału świadomości, mechanizmy adaptacyjne, które na podstawie sumy doświadczeń 
wynikających z interakcji ze środowiskiem stopniowo budują model nowego języka. Możemy więc powiedzieć, że bezwiedne nabywanie kompetencji językowych $w$ takim środowisku jest mechanizmem adaptacyjnym. Należy podkreślić, że nie mówimy o biernej ekspozycji na język, ale o aktywnym funkcjonowaniu w środowisku nasyconym językiem, gdzie jego używanie staje się jedną z kompetencji niezbędnych do funkcjonowania jednostki w tym środowisku. Tradycyjnie nauczanie immersyjne języka obcego oparte było na immersji społecznej, a więc umieszczeniu osoby przyswajającej język w środowisku, w którym inne osoby posługiwały się tylko tym językiem (jako ich językiem ojczystym), co prowadziło do sytuacji, kiedy używanie tego języka było warunkiem skutecznego funkcjonowania w nowym otoczeniu.

Metoda immersyjno-medialna wykorzystuje te doświadczenia, proponując proces akwizycji języka w środowisku medialnym, gdzie zanurzenie $\mathrm{w}$ mediach jest tożsame $\mathrm{z}$ zanurzeniem $\mathrm{w}$ środowisku językowym, jak również interaktywnym środowisku społecznym. Ogólnodostępne multimedialne zasoby Internetu stanowią idealny materiał do zbudowania takiego właśnie środowiska, które dodatkowo uruchamia mechanizmy poznawcze, gdyż uczenie się języka i odkrywanie świata oraz funkcjonowanie w wybranych grupach społecznych są tutaj nierozerwalnie połączone. Dodatkowo można zauważyć, że zanurzenie $\mathrm{w}$ takich mediach, połączone $\mathrm{z}$ immersją językową, odtwarza w sposób bardzo wierny pierwotne środowisko immersyjne, w którym nabywaliśmy nasz język rodzimy (co było również cechą tradycyjnie rozumianego nauczania poprzez immersję). Podobnie jak tam - mamy tu do czynienia z językiem jako elementem negocjacyjnym między osobą a rzeczywistością pozajęzykową, która jest poprzez język poznawana, eksplorowana i modyfikowana podczas interakcji językowej. Zdecydowaną przewagą naszej metody jest jednak znaczeniowe, językowe i poznawcze bogactwo środowiska medialnego, które byłoby niemożliwe do osiągnięcia tradycyjnymi metodami.

Nasza metoda opiera się również na zasadniczo innym rozumieniu języka (a w konsekwencji zastosowaniu odpowiednich dla takiego rozumienia pryncypiów metodycznych) niż język rozumiany jako niezależny od osoby ucznia sposób kodowania wiadomości lub zestaw sprawności gramatycznych i kompetencji słownikowych. Ten model, który niestety dominuje nadal zarówno $\mathrm{w}$ teorii, jak i w praktyce nauczania, pociąga za sobą planową odtwórczość aktywności ucznia i nastawienie na poprawność, które w praktyce uniemożliwiają kreatywność u ucznia i wpajają mu głębokie przekonanie, że najważniejszą cechą języka, którym będą się "posługiwać”, jest liczba błędów, którą trzeba minimalizować. $W$ tej perspektywie nauczany język na zawsze pozostanie językiem obcym, nigdy nie będzie zaadoptowany jako własny. 
W przeciwieństwie do tego odhumanizowanego widzenia języka (z którego wynika wszechobecność pamięciowo zorientowanych i niewymagających kreatywności testów jako miernika kompetencji językowych) immersja językowa oferuje zindywidualizowaną ścieżkę poznawania języka, promowanie ekspresji i eksperymentowania $w$ ramach języka oraz wynikającą stąd jego akceptację, a także możliwą internalizację.

\section{EWALUACJA SKUTECZNOŚCI METODY}

Nasza metoda stała się przedmiotem badań eksperymentalnych w celu określenia jej skuteczności. Eksperymentalny program zajęć oparty na naszej metodzie został przeprowadzony w roku szkolnym 2010/11 na podstawie innowacji dydaktycznej „Tablica interaktywna Twoim oknem na świat", zatwierdzonej przez profesora Wacława Strykowskiego i Zakład Nowoczesnych Technologii Nauczania UAM w Poznaniu. Zajęcia te były integralną częścią nauczania języka angielskiego w klasie III gimnazjum i obejmowały $50 \%$ jednostek „lekcyjnych w roku szkolnym. W trakcie zajęć głównym tematem był serial "Southpark" w połączeniu z regularnym przeglądaniem i komentowaniem internetowych serwisów informacyjnych, takich jak Time, BBC, Euronews. Zajęcia odbywały się w zgodzie z filozofią nauczania humanistycznego i nauczania responsywnego. Dzięki obecności serialu "Southpark" oraz wspólnej eksploracji zasobów Internetu udało się spełnić kluczowe założenia naszej metody nauczania języka, co przedstawiamy poniżej.

Umieszczenie doświadczenia, jak i aktywności językowych w cyberprzestrzeni zapewniło autentyczność materiału, która oznacza nie tylko autentyczność źródła językowego, ale przede wszystkim uznanie materiału za autentyczny przez uczniów, czyli ich akceptację serialu i internetowej społeczności fanów "Southpark” jako ważnego dla nich i powiązanego znaczeniowo $\mathrm{z}$ ich światem. Umożliwiło to również aktywację ego $\mathrm{w}$ procesie uczenia się - dzięki tak podobnej perspektywie widzenia świata i ważnych dla nastolatków na całym świecie problemów udało się stworzyć emocjonalną relację między uczniami i bohaterami serialu oraz skupioną wokół portalu Southpark społecznością internetową.

Dzięki rezygnacji z klasycznego podręcznika wprowadziliśmy jakość poznawczo- kulturową, która w odróżnieniu od tradycyjnego nauczania elementów kultury krajów anglojęzycznych (obejmującego historię rodziny królewskiej w Anglii lub historię pomników w Londynie) dała uczniom wgląd i zrozumienie bieżących problemów etnicznych, politycznych i społecznych w USA, na przykład problem nielegalnych imigrantów, wojen na 
Bliskim Wschodzie, sytuacji mniejszości seksualnych itp. Aktywności uczniów budowaliśmy na wyrażaniu opinii, dyskusjach i indywidualnych ścieżkach poznawczych zgodnie z semiotyczną perspektywą rozumienia języka jako części procesów poznawania świata i swobodnego wyrażania siebie.

Zmienienie ról nauczyciela i ucznia miało pozytywne skutki poznawcze i psychologiczne. Umożliwiło to uczniom dokonywanie aktywnych wyborów tematów i zawartości swoich aktywności językowych (zgodnie z założeniami teorii samookreślenia). Samopotwierdzenie własnej wartości na forum społecznym osiągnęliśmy dzięki prezentowaniu własnych zainteresowań i odkryć w Internecie na forum klasy. Równie ważne okazało się silne zaangażowanie czynnika emocjonalnego, dzięki gorącym nieraz dyskusjom na przedstawiane powyżej i zbliżone tematy. Prowadziliśmy też wspólną z uczniami eksplorację mediów, w trakcie której stali się oni niezależnymi odkrywcami języka i świata, gdzie nauczyciel był jedynie ich przewodnikiem i doradcą.

Klasyczne strategie nauczania stosowaliśmy wyłącznie dla tematów związanych z gramatyką; jak wynika z naszego doświadczenia, to jedyny obszar, w którym instrukcje formalne są przydatne dla uzupełnienia spontanicznej akwizycji języka. Pozwoliło to również przygotować uczniów do testowego egzaminu gimnazjalnego. Okazało się, że do osiągnięcia wysokich wyników, nawet na tak jednostronnie zaprojektowanym egzaminie, potrzebna była niewielka liczba takich instrukcji formalnych uzupełniających procesy akwizycji języka, które w naszym programie pełniły rolę kluczową.

Rezygnacja z pamięciowego opanowywania kolejnych działów słownictwa i popularyzacja systemu Super Memo sprawdziła się u większości uczniów - część pozostała przy metodach tradycyjnych. Zgodnie z wyznawaną filozofią nauczania responsywnego ta metoda nie była im narzucana.

O obiektywnej wymiernej skuteczności tego programu wystarczy powiedzieć, że uczniowie z nieelitarnej szkoły osiągnęli średni wynik z egzaminu gimnazjalnego z języka angielskiego wynoszący $82 \%$, a jednocześnie w subiektywnej ocenie uczniów atrakcyjność takich zajęć mierzona w wielu kategoriach okazała się trzykrotnie wyższa od znanych im do tej pory podręczników szkolnych (Szymiec, 2012, s. 453). Metoda immersyjno-medialna jest zatem skuteczną i zorientowaną przyszłościowo metodą, która oferuje efektywne przyswajanie języka w bogatym znaczeniowo i naturalnym dla uczniów środowisku, oparte na zindywidualizowanych ścieżkach uczenia się. Jej upowszechnienie będzie jednak wymagało wyposażenia nauczycieli języka $\mathrm{w}$ szeroki zakres kompetencji medialnych i wiedzę z pedagogiki medialnej, których nie naucza się jeszcze na studiach językowych. 


\section{WNIOSKI I UWAGI KOŃCOWE}

Jednym z najważniejszych i najczęściej ostatnio dyskutowanych słów dotyczących technologii, kultury i społeczeństwa jako takiego jest Singularity. Teoria ta, stanowiąca ekstrapolację obecnych trendów w technologiach informacyjnych, obejmuje dwie płaszczyzny.

$\mathrm{Z}$ jednej strony sugeruje ona, że ciągle rosnący udział komputera - a w konsekwencji jego niezbędność w realizacji większości zadań zawodowych i społecznych - doprowadzi w końcu do praktycznej nierozłączności z jego użytkownikiem. Tę płaszczyznę można by nazwać integracją funkcjonalną. Dla wielu osób przewidywania te w dużej mierze już się sprawdziły, a potwierdza je ciągłe zapotrzebowanie na kolejne coraz bardziej skomplikowane urządzenia. Na przykład wielkim zainteresowaniem cieszą się wprowadzane obecnie do użytku interaktywne okulary Google-glasses łączące funkcję GPS, połączenia internetowego, telefonu i urządzenia do wideokonferencji. Użytkownik widzi jednocześnie obraz rzeczywisty oraz nałożoną na niego zawartość różnych mediów elektronicznych. Na przykład jedząc obiad, można symultanicznie prowadzić wideokonferencję i kontynuować ją, jadąc tramwajem. Takie jednoczesne zanurzenie w mediach i obecność w świecie realnym, które są powiązane funkcjonalnie, nazywa się rzeczywistością poszerzoną - Augmented Reality.

Drugą płaszczyzną stanie się połączenie komputera i użytkownika przybierające formę fizyczną. Tutaj prowadzi się badania nad integracją układu nerwowego z obwodami cyfrowymi. Przykładem sukcesu takiej technologii jest przywracanie wzroku niewidzącym osobom, dokonywane dzięki wszczepieniu fotoreceptorów i połączeniu ich z wiązkami nerwowymi otrzymującymi spreparowany odpowiednio, przez również wszczepione podzespoły komputerowe, sygnał elektryczny. Dalej droga przetwarzania obrazu odbywa się już w normalnym trybie. Podłączenie układu nerwowego do stałej pracy $\mathrm{w}$ połączeniu $\mathrm{z}$ komputerem i sterowanie nim bez urządzeń pośredniczących jest, naszym zdaniem, tylko kwestią czasu.

Idea stopniowego zespalania człowieka z komputerem ma wielu zwolenników, ale też niestety wielu przeciwników. Zwolennicy mówią o konieczności uzyskania takiego połączenia dla dalszego rozwoju cywilizacji. Przeciwnicy próbują nas straszyć widmem doktora Frankensteina (choć osoby, którym przywrócono wzrok, do jej przeciwników nie należą). Wszystkie wielkie idee wymyślone przez ludzkość spotykały się z oporem środowisk konserwatywnych i tradycjonalistycznych, którego siła była wprost proporcjonalna do ich wagi. Oceniając pracę i postępy cybernetyki, stajemy zdecydowanie po stronie Giordano Bruno, a nie inkwizycji. Wprowadzone w Polsce już w latach 70. hasło „Edukacja dla przyszłości” w świetle tych rozważań nabiera coraz większej wagi i w tę perspektywę wpisuje się proponowane nauczanie poprzez zanurzenie w mediach. 


\section{LITERATURA}

Andersen N., Making a Case for Media Literacy in the Classroom, <http:/ / www.medialit. org/reading-room/making-case-media-literacy-classroom>, [dostęp: 15.07.2012].

Baranger M., Chaos, Complexity, and Entropy, Center for Theoretical Physics, Laboratory for Nuclear Science and Department of Physics Massachusetts Institute of Technology, Cambridge USA 2006.

Bloom S., Chaos, complexity, self organization and us, Psychoterapyreview 2.8, Communityworks, PMB 138/12 West Willow Grove Avenue, Philadelphia 2000.

Daily Mail, <http://www.dailymail.co.uk>, [dostęp: 21.05.2012].

Dylak S., Kompetencje medialne jako ważny nurt w edukacji humanistycznej, [w:] W. Strykowski, W. Skrzydlewski, Kompetencje medialne społeczeństwa wiedzy, Wyd. eMPi², Poznań 2004.

Eggen P., Kauchak D., Educational Psychology Windows to the Classroom, Merill Prentice Hall, New Jersey Columbus Ohio, USA 2004.

Harshbarger B., Chaos, Complexity and Language Learning, "Language Research Bulletin” 2005, 22.

Macrae F.P., Obsessed with mobiles and Ipads are guilty of child neglect, Daily Mail 2012.

Media Smarts Canada's Center for Media and Digital Literacy, <http://mediasmarts. ca/>, [dostęp: 18.07.2012].

Meg S., Managed Chaos: Learning in Technology Enhanced Environments, UCF Library The University of Central Florida Orlando, FL 32816, EDUCAUSE Nashville 2000.

Militiadis L., Thechnology Enchanced Learning, Best Practices, IGI Publishing, Hershey, New York 2008.

Skrzydlewski W., Kompetencje medialne, edukacja, rynek pracy i funkcjonowanie społeczne, [w:] W. Strykowski, W. Skrzydlewski, Kompetencje medialne społeczeństwa wiedzy, Wyd. eMPi², Poznań 2004.

Strykowska J., Monografia naukowa XVII Tatrzańskiego Sympozjum Naukowego: „Edukacja Jutra", Wyższa Szkoła Humanitas, Zakopane 2013.

Strykowski W., Kompetencje medialne: pojęcie, obszary, formy ksztatcenia, [w:] W. Strykowski, W. Skrzydlewski, Kompetencje medialne społeczeństwa wiedzy, Wyd. eMPi², Poznań 2004.

Szymiec R., Edukacja medialna w perspektywie ekologicznej, [w:] W. Skrzydlewski, S. Dylak (red.), Media - Edukacja - Kultura. W strone edukacji medialnej, Wyd. Uniwersytetu Rzeszowskiego, Rzeszów 2012.

Van Lier L., Ecology and Semiotics of language learning, Kluwer Academic Publishers, Norwell USA, 1996. 